\title{
İnek Konforunun Topallıklar Üzerine Etkisi ve Konforun Değerlendirilmesi
}

\author{
Mehmet AKKÖSE ${ }^{1 *}$, Celal İZCi \\ ${ }^{1}$ Tarım İşletmeleri Genel Müdürlüğü (TİGEM), Ceylanpınar Tarım İşletmesi, Şanlıurfa \\ ${ }^{2}$ Selçuk Üniversitesi, Veteriner Fakültesi, Cerrahi Anabilim Dalı, Konya \\ *İletişim (correspondence): e-posta: akkosem2012@gmail.com ; Tel: +90 (539)2022543 \\ Gönderim tarihi (Received): 20 Haziran 2016; Kabul tarihi (Accepted): 04 Ağustos 2016
}

\section{$\ddot{O} z$}

Topallık, modern süt sığırcılığında hayvanların verimini, sağlığını ve refahını etkileyerek ciddi miktarlarda ekonomik kayıplara neden olmaktadır. Ayak hastalıklarının ortak bir göstergesi olan topallıklar, multifaktoriyel etiyolojiye sahiptir. Bunlar ineğe bağı faktörler ve sürüye bağlı faktörler olarak iki gruba ayrılabilir. Sürüye bağlı faktörlerden olan inek konforu (özellikle geçiş dönemindeki ineklerin konforu) topallık nedeni olarak büyük öneme sahiptir. Topallığın başlatıcı faktörleri (buzağılama, besleme, travma) zayıf inek konforu ile şiddetlenebilir. İnek konforunun düşmesi, yeni topallık olgularının gelişmesine ve topal ineklerin iyileşme süresinin uzamasına neden olarak topallık insidensini etkiler. Dinlenme süresinin azalması ineklerin sert zeminlere maruz kalma süresini de uzatacaktır. İnek konforu, inek konfor indeksi (IKİ), durak kullanım indeksi, durakta bekleme indeksi, tarsal ve karpal eklem puanlamaları veya hijyen puanlaması gibi yöntemlerle değerlendirilebilmektedir. Bu derlemenin amacı serbest duraklı ahırlarda barındırılan süt ineklerinde, inek konforunun topallık oluşumundaki önemini değerlendirmek ve inek konforunun değerlendirilmesinde kullanılan yöntemler hakkında bilgi vermektir.

Anahtar kelimeler: Topallık, inek konforu, ahır zemini, durak düzenlemesi, geçiş dönemi

\section{The Impact of Cow Comfort on Lameness and Evaluation of the Comfort}

\begin{abstract}
Lameness is one of the most important welfare, health, and productivity problems in modern dairy production and causes significant economic losses. Lameness which a common indicators of foot diseases, has a multifactorial etiology. These can be separate two main group such as factors associated with the cow-level and herd-level factors. The cow comfort (especially the comfort of the transition cow) which was one of the herd-level factors has major importance as the cause of lameness. The trigger factors for lameness (calving, nutrition, trauma) can all be exacerbated by poor cow comfort. Reduced cow comfort influences lameness incidence by increasing the risk for development of new cases and the time it takes for a cow to recover. Reduction in resting time will increase the cow's exposure to hard flooring surfaces. Cow comfort can evaluate some factors such as cow comfort index (CCI), stall use index, stall standing index, tarsal and carpal joint scores or hygiene score. Aim of this review is to evaluate the importance of cow comfort on the occurrence of lameness and to inform about the metods which utilize cow comfort evaluation in dairy cows housed in free stall barn.
\end{abstract}

Keywords: Lameness, cow comfort, barn surface, stall design, transition period

\section{Giriş}

Topallık modern süt sığırcılığında hayvanların verimini, sağlığını ve refahını etkileyen en önemli sorunlardan biridir. Topallıklar ineklerin süt veriminde yaklaşık \%30'lara varan bir düşüşe neden olmaktadır (Warnick ve ark., 2001; Hernandez ve ark., 2005b; Yaylak, 2008). Ayrıca topal ineklerin ovaryum fonksiyonları aksamakta, kızgınlık belirtilerini yeterince gösterememekte, ve buzağılama aralıkları uzamaktadır (Chapinal ve ark., 2013; Garbarino ve ark., 2004; Hernandez ve ark., 2005a; Walker ve ark., 2008; Yaylak, 2008). Diğer yandan topal ineklerin birçoğunun ekonomik ömürlerini tamamlamadan kesime sevk edilmesi nedeniyle (Booth ve ark., 2004;
Solano, 2013; Sprecher ve ark., 1997) sürü ömürleri kısalmakta ve sürünün ayıklama oranları artmaktadır. Ayrıca topallıklar ineklerin şiddetli ağrı ve acı çekmesine neden olarak hayvan refahı açısından da sorun oluşturmaktadır (O’Callaghan ve ark., 2003).

Yapılan araştırmalarda topallık prevalansının \% 1,8 - \% 69 arasında değiştiği (Akköse ve İzci, 2017) ve ineklerin \% 20 - \% 25'inde klinik olarak topallık bulunduğu bildirilmektedir (Cook, 2007). Süt sığırcilı̆̆ işletmelerinde düzenli olarak ineklerin topallık durumları değerlendirilerek topallık insidensi ve prevalansı takip edilmelidir (Cook, 2007). İneklerin topal olup 
olmadıklarının saptanmasında objektif ve subjektif yöntemler kullanılmaktadır (Yaylak, 2008). Sprecher ve ark. (1997)'nın geliştirdiği beş dereceli puanlama sistemi serbest tip ahırlar için uygun olup, sürüde topallığın şiddetini ve yaygınlığını hızlı, kolay ve doğru bir şekilde saptamada oldukça kullanışlıdır (Yaylak, 2008). Bu puanlama sistemine göre ineklere 1 ile 5 arasında değişen topallık puanı (TP) (1 puan, sağlam; 2 puan, hafif topal; 3 puan, orta derecede topal; 4 puan, belirgin topal; 5 puan, şiddetli topal) verilmekte, TP 3 ve üzerindeki hayvanlar klinik olarak topal kabul edilmektedir (Espejo ve ark., 2006). Sürüde TP 1 olan hayvanların oranı \% 65 'ten fazla, TP 4 ve 5 olanların oranı ise \% 3 'ten az olmalıdır (Cook, 2007; İzci ve ark., 2016). Topallık puanlamasının asıl amaçlarından birisi de subklinik topllık dönemindeki (TP 2) ve klinik topallığın başlangıcındaki (TP 3) hayvanların tespit edilmesidir. Bu hayvanlara en kısa sürede fonksiyonel tırnak kesimi yapılmalıdır. Böylece ayak hastalıklarının oluşması önlenebilmekte veya var olan bir ayak hastalığı çok erken safhadayken tespit edilip kolayca tedavi edilebilmektedir (Manske ve ark., 2002; İzci ve ark., 2016).

Topallığa neden olan ayak hastalıkları "enfeksiyöz ayak hastalıkları" ve "boynuz ve canlı tırnak lezyonları (BCTL)" olmak üzere iki ana grupta toplanabilir. Boynuz ve canlı tırnak lezyonları taban hemorajileri, taban ülseri, parmak ucu ülseri, ökçe ülseri, beyaz çizgi hastalığı, tırnak çatlakları ve çift taban oluşumu iken; enfeksiyöz ayak hastalıkları digital dermatitis, interdigital flegmon ve ökçe erezyonudur (Cook, 2007). Enfeksiyöz ayak hastalıkları bu predispoze faktörler arasından daha çok hijyen problemi ile ilgili iken, BCTL ise multi-faktoriyel etiyolojiye sahiptir.

Doğum, besleme (mikro besin maddelerinin yetersizliği, kaba ve yoğun yem oranı, yemdeki protein, enerji düzeyleri, doğum öncesi yemleme) ve travmalar topallıkları başlatıcı (yapıcı) faktör olarak rol oynamaktadır (Cook, 2007; Novek, 1997). Bu yapıc1 faktörlerin yanında sütçü sığırlarda topallıkların inek (bireysel) ve sürü düzeyinde çok sayıda predispoze (risk) faktörü bulunmaktadır (Akköse ve İzci, 2017; Yaylak ve ark 2010). Bunlardan 1rk, yaş, gebelik ve laktasyon döneminde (özellikle doğum sürecinde) tırnaklarda şekillenen fizyolojik değişiklikler, ineğin daha önce geçirdiği hastalıklar, vücut kondisyon puanı (VKP) ve genetik yatkınlık bireysel faktörlerdir. Sürüye bağlı faktörler ise inek konforu, ayak ve tırnak hijyeni, inekler arasındaki sosyal baskınlık, çiftlik içi inek hareketleri, rasyon ve fonksiyonel tırnak kesimidir (Mülling ve ark, 2006; Yaylak ve ark., 2010).
İnek konforunun iyi olması, topallı̆̆ başlatan faktörlerin etkilerini azaltarak topallık oluşumunu önler. Ayrıca topallık süresince topal hayvanların ağrılarını hafifleterek ve yaşam koşullarını iyileştirerek, topallığa neden olan ayak hastalıklarının tedavi sürecine olumlu katkılar yapar (Cook 2007). İnek konforunun kötü olması topallığın başlatıcı faktörlerinin etkilerini şiddetlendirir. Yeni topallık olgularının gelişmesine ve topal ineklerin iyileşme süresinin uzamasına neden olarak topallık insidensini etkiler. Ayrıca sığırların dinlenme süresinin azalmasına neden olarak sert zeminlere maruz kalma süresini de uzatır (Endres 2017).

\section{Doğum Sürecinde Tırnaklarda Şekillenen Değişiklikler}

Ayak hastalıkları bakımından doğum süreci tanımlaması, doğumdan önceki yaklaşık bir aylık süre ile doğum ve doğumdan sonraki 2-3 aylık süreyi kapsar. Buzağılamadan sonraki 2. ve 3. aylarda topallıkların pik yapması, doğum süreci ile topallık oluşumu arasında önemli bir ilişkinin varlığının göstergesidir (Blowey, 2005). Doğum bir inek için önemli derecede yıkıcı etkileri olan bir süreçtir (Toussaint Raven, 2003). Bu dönemde tırnak sağlığını olumsuz etkileyen çok sayıda fizyolojik, metabolik ve davranışla ilgili değişiklikler şekillenir. Meydana gelen değişiklerden birisi üçüncü falanksın (tırnak kemiğinin) tırnak içindeki hareketliliğinin artmasıdır. Tarlton ve ark. (2002) tarafindan doğum sürecindeki düvelerin tırnaklarında "hoofase" adı verilen gelatinolitik etkili bir enzimin tespit edilmiştir. Tırnaklardaki hoofase enziminin aktivitesi doğumdan önceki ikinci haftadan başlayarak doğumdan sonraki üçüncü aya kadar artarak devam etmektedir. Araştırıcılar tarafından, bu enzimin vücutta elastik liflerin yıkımlanmasından sorumlu olan enzimlerden matriks metalloproteninaz-2'yi (MMP-2) aktive ettiği belirtilmektedir (Tarlton ve ark., 2002; Tarlton ve Webster, 2002). Diğer yandan doğumun gerçekleşmesini sağlayan hormonal etkiler (özellikle relaksin) vücuttaki tüm ligament ve tendoların gevşemesine neden olduğu gibi, ayağın asıcı bağ sistemi (suspensory apparatus) ve destek sisteminin (supportive apparatus) gevşemesine de neden olmaktadırlar (Blowey, 2015; Shearer, 2010). Gerek artan hoofase aktivitesi gerekse doğum sürecindeki hormonal değişim nedeniyle geçiş dönemindeki ineklerde, tırnak kemiğinin hareketliliği önemli derecede artmaktadır (Blowey, 2015; Lischer ve Ossent, 2002; Mülling, 2009). Bu artış tırnağın canlı dokusunda şidddetli travmalara ve kanamalara yol açmaktadır. 
Doğum sürecinde, tırnaklarda meydana gelen değişikliklerden birisi de ökçe yastığının kalınlığının azalmasıdır. Tırnak kemiği ile tırnağın canlı dokusu arasında yerleşim gösteren ve yağ dokudan oluşan ökçe yastığının görevi, ineğin ayaklarına binen yükü absorbe etmek ve taban koryumunun ezilmesini engellemektir. Doğumdan sonra negatif enerji dengesi boyunca, vücut kondüsyonu kaybıyla paralel olarak, ökçe yastığının kalınlığının da azaldığı belirtilmektedir (Newsome ve ark., 2017a,b). Bu azalma boynuz tırnak içinde travmatik etkilerin artmasına yol açarak, BCTL'ye yatkınlığın oluşmasına neden olmaktadır (Bicalho, 2011; İzci ve ark., 2011; Mülling, 2009; Shearer, 2010).

Doğum sürecinde boynuz tırnak üretiminde bir azalma olmakta, üretilen tırnağın kalitesi düşmekte ve tırnak aşınması artmaktadır (Blowey, 2005). Nitekim ineklerin boynuzlarındaki yaş halkaları doğum sürecinde boynuz doku üretiminin azaldığının göstergesidir. Doğum sürecinde tırnak üretiminin azalması ve üretilen tırnağın kalitesinin düşmesinde, sistin ve metiyonin gibi kükürtlü aminoasitlerin ve serum proteinlerinin (albümin, globülin) kandaki düzeylerinin azalmasının etkili olabileceği düşünülmektedir. Doğumla birlikte önemli düzeyde serum proteini ve kükürtlü aminoasit süt üretimi için harcanmaktadır. Serum proteinlerin azalması damarlardaki onkotik basıncın düşmesine neden olarak kanın sıvı kısmının damar dışına çıkmasına ve vücudun çeşitli bölgelerinde ödem oluşumuna (doğum sürecindeki hayvanlarda şekillenen meme ödemi gibi) neden olur. Benzer şekilde tırnaklardaki kan dolaşımının da bozulduğu belirtilmektedir. Kükürtlü aminoasitler ise boynuz tırnağın yapısına katılırlar. Sonuç olarak canlı tırnak yeterince beslenemez, boynuz tırnak üretimi azalır, üretilen tırnağın kalitesi düşer ve düşük kalitedeki tırnakların aşınması da artar (Blowey, 2015).

Doğum sürecindeki ineklerin davranışlarında da değişiklikler gözlenir (Huzzey ve ark, 2005). Bu dönemde ineklerin daha uzun süre ayakta bekledikleri ve yatma sürelerinin kısaldığı belirtilmektedir (Huzzey ve ark., 2005). Yapılan çalışmalarda postpartum dönemde topallık şekillenen ineklerin, geçiş döneminde daha az yattıkları tespit edilmiştir (Proudfoot ve ark., 2010; SepulvedaVaras ve ark., 2014).

Doğumu başlatmak için salınan fötal kortizolün de laminitis oluşumunda etkili olabileceği belirtilmektedir (Blowey, 2015).

\section{İnek Konforu}

İnekler, dinlenmek ve yürümek için yumuşak yerleri tercih ederler (Herlin, 1997; Telezhenko ve Bergsten, 2005; Telezhenko ve ark., 2007) ve yumuşak yerlerde daha uzun süre yatarlar ve daha az ayakta dururlar (Herlin, 1997). İyi bir şekilde tasarlanmış ve düzenli olarak bakımı yapılan serbest duraklar ineklerin ayakta durma süresini azaltır, geviş getirme etkinliğini artırır, ineklerin ve durakların daha temiz olmasını sağlar ve yaralanmaları en aza indirir (Graves ve ark., 2009). BTCL ile inek tırnaklarının sert ve aşındırıcı zeminlere maruz kalması arasında da bir ilişki vardır (Bergsten, 2010). Ahır zeminin konforunun arttırılması (servis yollarına kauçuk mat serilmesi gibi) BCTL insidensini azaltmaktadır (Bergsten, 2010; Fjeldaas ve ark., 2011; Norberg, 2013). Süt sığırlarının refahı, sağlı̆̆ı ve verimliliği için hayvanların dinlenme ihtiyaçlarını karşılayabilecekleri rahat kuru ve temiz yatma alanları sağlanmalı ve yürüyüş konforunu arttıran zemin düzenlemeleri yapılmalıdır. Ayyılmaz ve ark. (2011a), ineklerin dinlenme ihtiyaçlarının karşılanmasında inek konforunu esas alan durak tasarımının önemini vurgulamışlardır.

\section{Yatma İhtiyacı}

Dinlenme, sığırlar için çok yüksek öncelikli bir ihtiyaçtır (Munksgaard ve ark., 2005). İnekler bu ihtiyaçlarını karşılayabilmek için günlük 12-14 saat süreyle yatarlar (Blowey, 2005). Topallık ile yatmama arasında çok önemli bir ilişki bulunduğu (Dippel ve ark., 2009) ve yatma süresinin azalmasina neden olan herhangi bir faktörün, özellikle koryumun çok frajil (kırılgan) olduğu postpartum dönemde, BCTL insidensinde belirgin bir artışa neden olduğu belirtilmektedir (Blowey, 2005). İneğin uzun süre ayakta durması tırnaklara binen yükün artmasına neden olarak koryumda (tırmağın canlı dokusu) travmatik lezyonların şekillenmesine yol açmaktadır (Bell ve Weary, 2000). Bu nedenle ineklerin barındırılmasında en önemli hususlardan biri, ineklerin dinlenme ihtiyaçlarını karşılayabileceği rahat bir yatma yerinin sağlanması olmalıdır (Ayyılmaz ve ark., 2011a; Ayyılmaz ve ark., 2011b).

\section{Barınak Tipi}

Topallık prevalansının serbest duraklı ahır sistemlerinde bağlı duraklı ahırlara göre daha yüksek olduğu belirtilmektedir (Cook 2003; Sogstad ve ark., 2005). Bu durum barınak sistemlerinin, sütçü sığırların topallıklarıyla doğrudan ilişkili olduğu göstermektedir (Cook 2003; Haskell ve ark., 2006; Sogstad ve ark., 2005; Vanegas ve ark., 2006). Serbest duraklı ahırlarda 
“ineklerin yatma süresini azaltan faktörler” ve “ahırın zemin özellikleri” önemli topallık sebepleri olarak karşımıza çıkmaktadır. Durak konforunun yetersiz olması, durak ölçülerinin ineğin yatma ve yatış-kalkış davranışına uygun olmaması (Blowey, 2005) ve yeni doğum yapan düvelerin durak kullanmayı bilmemesi (von Keyserlingk ve ark., 2011) serbest duraklı ahırlarda yatma süresini azaltan en önemli faktörlerdir.

\section{Durak Konforu}

Altlık tipi ve altlık miktarı durak konforunu etkileyen önemli faktörlerdir (Endres, 2012). Duraklar ineklerin konforunu arttırmalı ve yaralanmalarını önlemelidir. Durak zemini yeterli 1sı izolasyonu sağlamalı, yeterince yumuşak olmalı, kaygan olmamalı, aşındırıcılığı en düşük düzeyde olmalı ve kolayca temizlenebilmelidir (van Eerdenburg, 2013). Durakların konforu ineğin yatma davranışını ve yatma süresini önemli ölçüde etkiler ve durak konforunun azalması ise topallık vakalarını arttırır (Gomez ve Cook, 2010; Solano, 2013; Vanegas ve ark., 2006). Durakların konforunu arttırmak için, "ineğe soralım" adı da verilen yöntemle, ineklerin farklı altlık malzemelerini tercih etme durumlarına göre yataklık seçimleri yapılmaktadır (Uslucan ve Özkütük, 2007). Organik (saman, talaş, kuru gübre vb), inorganik (kum) ve sentetik (yumuşak veya sert kauçuk mat, matress-inek yatağı vb) olmak üzere çok sayıda altlık malzemesi bulunmaktadır (Uslucan ve Özkütük, 2007). Günümüzde serbest duraklı ahırlarda durak tabanının düzenlemesi, derin altlıklı duraklar veya yatak kaplamalı duraklar olmak üzere iki şekilde yapılmaktadır (Ayyılmaz ve ark., 2011a; Ayyılmaz ve ark., 2011b). Derin altlıklı duraklarda altlık malzemesi olarak genellikle kum kullanılırken, yatak kaplamalı duraklarda, beton zemin üzerine matress yatak veya kauçuk mat serilmektedir (Ayyılmaz ve ark., 2011a; Graves ve ark., 2009). Matress yatakların içi kauçuk kırıntılarıyla dolu (kauçuk yatak), içi köpükle dolu (köpük yatak) ve içi su dulu (su yatağı) gibi çeşitleri bulunmaktadır (Ayyılmaz ve ark., 2011b). Kum altlıklar ve matress yataklar, beton yüzeyler ve kauçuk mat yataklara göre inekler tarafindan daha çok tercih edilmektedir (Wagner-Storch, 2003). Kum altlıklı durakların ineklerin yatma süresini arttırdığı ve mera ile kıyaslandığında yatma süreleri arasında belirgin bir farkın bulunmadığı belirtilmektedir (Margerison ve ark., 2014). İneklerin ayağa kalkması esnasında, matress veya mat gibi düz zeminlerde, tırnak ve zemin yüzeyi arasında çok az bir temas alanı oluşmakta (Şekil 1) ve böylece tırnak ucuna aşırı derecede yük binmektedir (Cook, 2008). Kum zeminlerde ise ineğin ayağa kalkması esnasında, tırnaklar kuma gömüldüğü için daha fazla temas alanı oluşurken tırnaklarındaki basınç tırnağın tüm dış yüzeyine yayılmaktadır (Cook, 2008). Bu nedenle kum altlıklı duraklarda topal olan ineklerin oranı matress yataklara göre daha düşüktür (Cook, 2003). Diğer bir açıdan kum zeminli duraklarda ineklerin (özellikle topal ineklerin) yatış-kalkış esnasındaki konforu da artmaktadır (Cook, 2008).

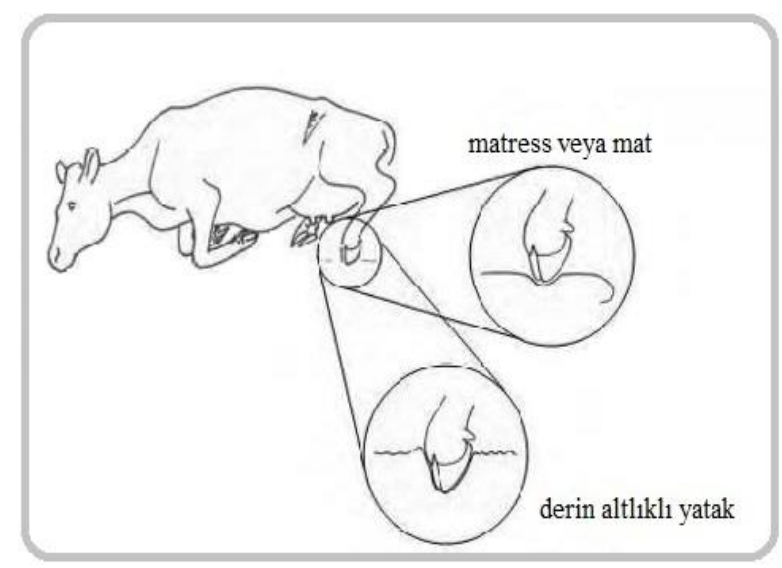

Şekil 1. Farklı zemin tiplerinde, ineklerin ayağa kalkması esnasında tırnak ve zemin yüzeyi arasındaki ilişki (Cook, 2008)

İneklerin durak tercihleri üzerine, durak malzemesinin yanı sıra durakta kullanılan altlık malzemesinin miktarı veya kalınlığı da etkilidir. Yapılan bir çalışmada matress yatakların üzerine odun talaşı serilerek $(0,1$ ve $7,5 \mathrm{~kg})$, ineklerin davranışları ve durak tercihleri değerlendirilmiştir (Tucker ve Weary, 2004). Çalışmanın sonuçlarına göre ineklerin odun talaşının daha çok serildiği durakları daha fazla tercih ettikleri ve bu duraklarda yatma süresinin daha uzun olduğu (matress üzerine $7,5 \mathrm{~kg}$ odun talaşı serildiğinde, yatma süresinin ortalama 1,5 saat uzadığı) görülmüştür (Tucker ve Weary, 2004). Drissler ve ark. (2005) altlık malzemesi olarak kum kullanılan derin altlıklı duraklarda, altlık kalınlığının her $1 \mathrm{~cm}$ azalmasıyla yatma süresinin 11 dakika kısaldığını belirtmektedir.

Beton zemine sahip duraklarda ineklerin kendilerini rahat hissetmemeleri nedeniyle yatma sürelerini oldukça kısalmaktadır (Greenough, 2007). Bir inek yatıp kalkarken ağırlığının büyük bir kısmı karpal eklemler tarafından taşınır. Eğer durak zemini sert ve aynı zamanda yüzeyi de pürüzlü ise bu tip duraklar inekler tarafindan pek tercih edilmez (Blowey, 2005). Yapılan araştırmalar, topallık insidensinin yataklık malzemesinin özelliklerine göre değiştiğini (Cook, 2003; Cook ve ark., 2004) ve durak konforu arttıkça topallık insidensinin azaldığını göstermektedir. Sonuç olarak, en iyi durağın en rahat durak olduğu belirtilmektedir (Blowey, 2005; Cook ve ark., 2004). 


\section{Durak Ölçüleri}

Durakların hayvanın ihtiyaçlarına uygun olarak tasarlanması oldukça önemlidir (Cook ve Nordlund, 2004a; van Eerdenburg, 2013). Durak ölçülerinin yetersiz olması, ineklerin duraklarda ayakta bekleme süresini uzatan önemli faktörlerden biridir. İnekler uzun, kısa, dar ve geniş olmak üzere dört farklı pozisyonda yatarak dinlenirler (Ayyılmaz ve ark., 2011a; Ayyılmaz ve ark., 2011b). Bir inek kalkarken önce karpal eklemlerini yere dayar, ileri doğru başıyla bir hamle yaparak arka ayaklarını kaldırır ve ön ayaklarından biriyle bir adım atarak doğrulur. Her bir durak, hayvan dinlenirken ve yatıp kalkarken (özellikle kalkarken) doğal vücut hareketlerini yapmasına izin verecek ölçülerde yapılmalıdır (Ayyılmaz ve ark., 2011a; Ayyılmaz ve ark., 2011b; Blowey 2005; van Eerdenburg, 2013). Şekil 2'de serbest bir durağın unsurları gösterilmektedir.

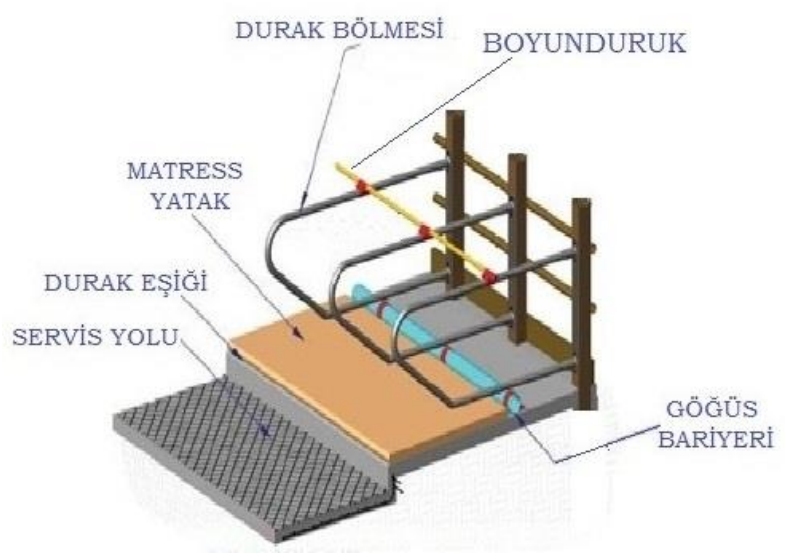

Şekil 2. Serbest durak unsurları (Graves ve ark., 2009)

Durak genişliği ve uzunluğu (Tucker ve ark., 2004), boyunduruk konumu (Bernardi ve ark.,2009; Fregonesi ve ark., 2009; Tucker ve ark., 2005), göğüs bariyerinin yüksekliği (Tucker ve ark., 2006), hamle alanının uzunluğu (Cook ve Nordlund, 2004a) ve durak eşiğinin yüksekliği (Solano ve ark., 2016) yatma süresini azaltan en önemli durak unsurlarıdır .

\section{Servis Yollart ve Gezinme Alanının Zemini}

Servis yolu ve gezinme alanlarının zemin tipi ve kalitesi ineklerde topallığın oluşumu üzerinde önemli bir rol oynamaktadır (Solano, 2013). Nitekim zeminlerin sertliği, aşındırıcılığı ve kayganlığının ayak ve bacak sağlığını olumsuz etkileyen faktörler olduğu bildirilmektedir (Greenough, 2007; Telezhenko ve ark., 2007).

Sert zeminlerin, sığırların tırnaklarına aşırı yük binmesine (Ouweltjes ve ark., 2011), özellikle rslak ortamlarda, tırnak aşınmasını arttırarak, tırnak tabanının incelmesine ve küt tırnak oluşumuna neden oldukları belirtilmektedir (Telezhenko ve ark., 2009). Yürüme zeminin kaygan olması ise düşmelere bağlı olarak ineklerin yaralanmalarına, yürüyüşlerinin (lokomosyon) bozulmasina (Phillips ve Morris, 2001; van der Tol ve ark., 2005) ve tırnağın canlı dokusunda travmatik etklere neden olarak, topallığın oluşmasına yol açmaktadır (Rushen ve de Passillé, 2009).

İnekler toprak zemin hayvanlarıdır. Yürümek ve yatmak için yumuşak yüzeyleri tercih ederler. Sert yüzeyler inekler için daha az konforludur ve tırnakların aşırı ve dengesiz uzamasını tetikleyerek, tırnaklardaki yük dağılım dengesinin bozulmasına yol açarlar ve böylelikle ineğin topal olmasına yatkınlık oluştururlar (Shearer ve van Amstel, 2007; Shearer, 2010).

Beton zeminlerde barındırılan ineklerde topallık oranının daha yüksek olduğu belirtilmektedir (Norberg, 2013). Serbest duraklı ahırlarda, uzun ömürlü olması ve kolay temizlenebilmesi gibi avantajlarıyla çoğunlukla beton zemin kullanılmaktadır (Bergsten, 2010; Vanegas ve ark., 2006). Beton, yap1 malzemesi olarak avantajlar sağlaması yanında inek tırnağı için oldukça sert ve aşındırıcıdır (Vanegas ve ark., 2006). Beton zeminler yeterli sürtünme sağlayamadığı için ineğin doğal yürüyüş davranışını yapmasına olanak tanımaz (van der Tol ve ark., 2005) ve ineklerin kayıp düşmelerine neden olur (Rushen ve de Passillé, 2009). Bu yüzden ineklerin yürümesi için beton zemin uygun değildir (Cook, 2007). Yumuşak kauçuk mat ise beton zeminlere göre daha iyi sürtünme kuvveti sağlar (Rushen ve de Passillé, 2009) ve tırnak sağlığı için daha yararlıdır (Vanegas ve ark., 2006). Vanegas ve ark. (2006), beton zeminlerin tırnağın uzama ve aşınma oranlarını arttırdığını saptamışlardır. Beton zeminler öncelikle ineğin tırnağını aşındırarak koryuma (tırnağın canlı dokusu) daha fazla yük binmesine neden olurlar ve böylece tırnak kemiğinin tabanındaki çıkıntılar koryumun tırnak üreten hücrelerini daha sık sitümüle eder. $\mathrm{Bu}$ sitümülasyon sonucunda, özellikle tırnak kemiğinin tabanında çıkıntıların yoğun olarak bulunduğu taban ökçe geçiş bölgesinde tırnak daha fazla uzar(Blowey, 2015). Tırnak tabanındaki aşırı uzama tırnakların kendi içindeki ve iki tırnağın birbiri arasındaki yük dağılım dengesini bozar (Shearer ve van Amstel, 2007).

Dışkı ve idrarı servis yollarından kolayca uzaklaştırabilmek için ızgaralı zeminler tasarlanmıştır. Nitekim 1zgaralı zeminlerde dijital dermatitis ve ökçe erezyonu insidensi daha düşük düzeyde saptanmıştır (Fjeldaas ve ark., 2011; Somers ve ark., 2005). Ancak 1zgaralı zeminler tırnakların zeminle temas eden kısımları daha fazla basınca maruz kalmaktadır. Bu ise BCTL riskini arttırmaktadır (Bergsten, 2013; Fjeldaas ve ark., 2011). 
Diğer yandan zeminlerin konforu hayvanın yürüyüşünü (lokomosyon) de etkilemektedir. Yumuşak zeminlerin hem topal hem de sağlıklı ineklerin yürüyüşünü iyileştirdiği bildirilmektedir (Telezhenko ve Bergsten, 2005). Zeminlerin yumuşaklığı zemin yüzeyinin sürtünmesini arttırarak kayganlığını azaltır (Rushen ve de Passillé, 2009). Yumuşak zeminlerde yürüyen hayvanların adım uzunluğu, beton zemindekilerle kıyaslandığında daha fazla iken (Telezhenko ve Bergsten, 2005), meradakilerle kıyaslandığında, aralarında belirgin bir farklılık bulunmamaktadır (Jungbluth ve ark., 2003; Norberg, 2013). Zemin sertliğinin azalması yürüyüş esnasında tırnaklara etkiyen basıncı da düşürür. Yine de kauçuk zeminler, çok sert olduklarında veya yeterli sürtünmeye sahip olmadıklarında kaygan olabilmektedirler (Rushen ve de Passillé, 2009).

İnekler ayakta beklerken zaman zaman arka ayaklarından birini kaldırır ve memesi ile bacağı arasındaki bölgeyi veya bacaklarını yalayarak temizlerler (caudal lickinggrooming) (Şekil 3). Hayvanlar bu temizlenme davranışlarını kendilerini güvende hissettikleri zeminlerde gösterirler (Hulsen, 2010). Platz ve ark. (2008) ineklerin mat zeminlerde beton zemine göre dört kat daha fazla temizlenme davranışı gösterdiğini bildirmektedir. Norberg (2013) de beton zemine göre mat zeminde bu davranışın daha fazla gözlendiğini belirtmektedir. İneklerin bu bölgeyi yalama davranışlarını yapmaları kauçuk mat zeminlerde kendilerini güvende hissettiklerini göstermektedir (Norberg, 2013). Bu sonuçlara bakarak servis yollarının konforunun beton yüzeylere kauçuk mat sererek arttırılabileceğini söylemek mümkündür. Günümüzde ticari olarak satılan farklı kalınlık ve tasarımda çok sayida kauçuk mat bulunmakta (Norberg, 2013) olup yetiştiriciler en uygununu seçmeye dikkat etmelidir.

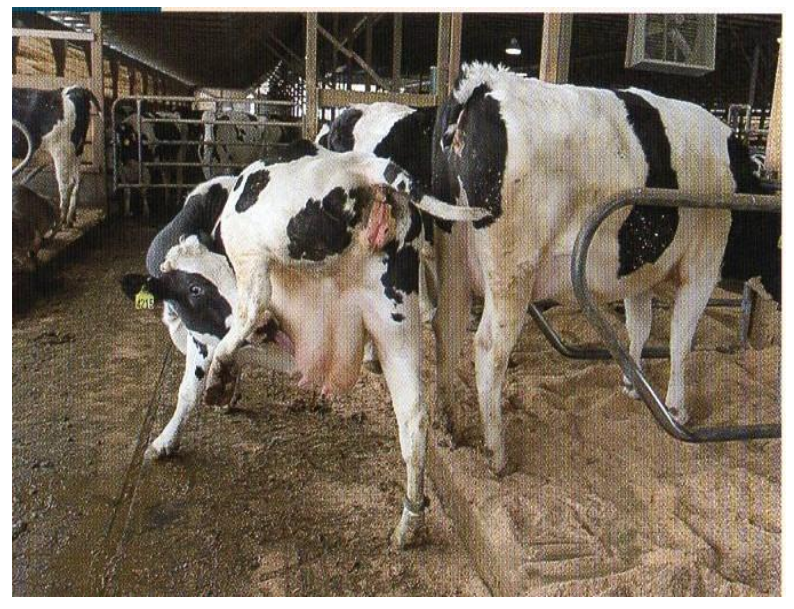

Şekil 3: İnekler bu davranışı kendilerini güvende hissettikleri zeminlerde gösterirler (Hulsen, 2010)

\section{Hijyen}

Uzun süre dışkı ve idrara maruz kalan tırnaklarda, tırnak dokusunun dayanıklılığının azaldığı ve bütünlügüüün daha çabuk bozulduğu belirtilmektedir (Mülling ve ark., 2006). Diğer yandan ahır hijyeninin kötü yani ahır zemininin ıslak, çamur kıvamında olması enfeksiyöz ayak hastalıklarının riskini artırmaktadır (Greenough, 2007). Zeminin sulu dışkı ile kaplı olması aynı zamanda interdigital derinin yumuşamasına ve mikroorganizmaların gelişmesi için uygun bir ortamın oluşmasına da yol açmaktadır. Ahır zeminlerinin yanı sıra meradaki sulukların etrafındaki çamur da ciddi bir enfeksiyon kaynağıdır (Greenough, 2007). Bu nedenle bütün zemin tiplerinin idrarı ve ortamdaki suyu uzaklaştıracak şekilde tasarlanması oldukça önemlidir. Bu amaçla ızgaralı veya oluklu zemin düzenlemeleri tasarlanmıştır. Izgaralı zeminlerde dışkı ve idrar çok kolay bir şekilde uzaklaştırılabilir. Ancak ızgaralı zeminlerin BCTL riskini arttırdığı da unutulmamalıdır. İdrar ve ortamdaki su yeterli eğime sahip zeminlerde, zemin yüzeyine açılan paralel oluklar sayesinde de uzaklaştırılabilir (Bergsten, 2013). Optimum zemin eğimi servis yollarında \% 1,5-3 ve sağımhanenin bekleme alanında \% 2-3 olmalıdır. Diğer yandan ineklerin bulunduğu herhangi bir alanda zemin eğiminin \% 6'dan fazla olmaması gerektiği belirtilmektedir. Eğimin fazla olduğu alanlar ( $>\% 6)$, mutlaka $15-20 \mathrm{~cm}$ yüksekliğindeki basamaklarla bölünerek, zemin eğimi azaltılmalıdır (Gooch, 2012).

Kirli ve ıslak ahır zemininin tırnak sağlığını olumsuz etkilemesinin yanısıra, ineklerin ayaklarının servis yollarındaki gübre sıyırıcılarının önüne toplanan dışkının içinde batması (tsunami etkisi) da tırnak sağlığını olumsuz etkilemektedir. Hem ıslak zeminlerin hem de sıyırıcıların önüne toplanan dışkının tırnak sağlığına olan olumsuz etkilerinin, yemlik önüne dikilme platformu inşa edilmesiyle (Şekil 4), büyük ölçüde önlenebileceği belirtilmektedir (Bergsten, 2013; Greenough, 2007).

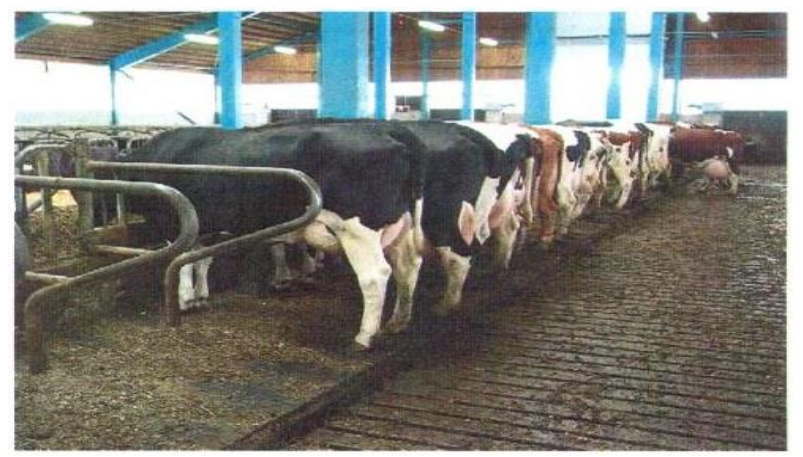

Şekil 4. Yemlik önündeki dikilme platformu, servis yolundaki dışkının ineklerin ayaklarına bulaşma riskini azaltır (Greenough, 2007) 


\section{Sicaklık Stresi}

Yüksek sıcaklıklar sığırların konforunu olumsuz etkilemektedir. Sicaklık stresine maruz kalan hayvanların günlük yatma süresi yaklaşık 3 saat kadar kısalmaktadır (Cook ve ark., 2007). Özellikle yaz mevsimi sonunda BCTL insidensindeki artışın önemli bir nedeninin de sıcaklık stresi sonucu yatma süresinin kısalması olarak belirtilmektedir (Cook ve ark., 2007). Sicaklık stresinin derecesi sıcaklık-nem indeksi (SNI) ile ölçülebilir. Üreme performansı ve süt verimi SNI'nin 72 ve üzerinde olduğunda olumsuz etkilenmekte ayrıca fizyolojik değişiklikler de görülmeye başlamaktadır. Aslında ineklerin yem yeme ve ayakta bekleme gibi davranışlarının SNI 68 olduğunda değişmeye başladığı bildirilmektedir (Cook ve ark., 2007; Gantner ve ark., 2011).

\section{İnek Konforunun Değerlendirilmesi}

İneklerin durak tercihleri, yatma ve ayakta bekleme süreleri, tarsal ve karpal eklem lezyonları gibi hayvanla ilgili çeşitli ölçütler inek konforunun değerlendirilmesinde kullanılmaktadır (Endres, 2012).

\section{Inek Konfor Índeksi}

İnek konfor indeksi (İKİ) sürüde ineklerin konfor düzeyini değerlendirmek için geliştirilmiş bir yöntemdir. İKİ ile sürüdeki topallık düzeyi arasında pozitif bir korelasyon bulunmaktadır (Greenough, 2007). İKİ duraklarda yatan ineklerin durakları kullanan tüm ineklere oranıdır ve sağımdan yaklaşık bir saat önce ineklerin durakta olma ve duraktaki ineklerin pozisyonları dikkate alınarak hesaplanmaktadır (Cook ve ark., 2005). Örneğin 100 baş inek bulunan bir ahırda 85 ineğin duraklarda bulunduğunu ve duraklardaki bu 85 inekten 70'inin yattığını, 15 ineğin de iki veya dört ayağıyla duraklarda dikiliyor olduğunu kabul edelim. Bu durumda İKİ, duraklarda yatan 70 ineğin, durakları kullanan 85 ineğe oranlanmasıyla $(70 / 85=0.82)$ hesaplanmaktadır. Konfor düzeyi normal olan ahırlarda İKİ \% 80-85 arasında olmalı, eğer bu sınırların altındaysa inek konforunu etkileyen faktörler gözden geçirilmelidir (Greenough, 2007).

\section{Durak Kullanım Indeksi}

Ahirda bulunan ve yem yemeyen ineklerin duraklarda yatan ineklere oranıdır. Sağımdan bir saat önce ölçüm yapılır ve \% 75'ten büyük olması istenir. Durak kullanım indeksi, inek konfor indeksine göre günün farklı vakitlerinde daha fazla değişim gösterdiği için güvenilirliği daha düşüktür (Cook ve ark., 2005).

\section{Durakta Bekleme İndeksi}

İnek konfor indeksinin zıttı olarak değerlendirilen bir indekstir. Duraklarda iki veya dört ayağıyla dikilen ineklerin duraklarda bulunan tüm ineklere oranıdır. Durakta bekleme indeksi sabah veya akşam sağımlarından 2 saat önce yapılan değerlendirmede \% 20'den daha fazla ise bu durum ineklerin günlük 2 saatten daha uzun süre duraklarda ayakta beklediği göstermektedir. Bu durumda, özellikle durakların yatmayı engelleyen faktörler yönünden yeniden gözden geçirilmesinde fayda bulunmaktadır (Cook ve ark., 2005).

\section{Tarsal Eklem Puanı}

Tarsal eklem lezyonları, durak konforunun yetersiz olduğunun bir göstergesidir. Bu puanlama sistemine göre tarsal bölgede kıl dökülmesinin olması veya hemoraji ve şişliklerin bulunması sorun olduğunu gösterir (Blowey, 2015). Tarsal eklem puanlaması dört dereceli (0-3) olarak yapılmaktadır (Şekil 5). (0 puan: şişkinlik yok, kıl dökülmesi çok az veya yok, 1 puan: şişkinlik yok veya hafif bir şişkinlik var, 2 puan: orta derecede şişkinlik [1$2,5 \mathrm{~cm}$ kalınlıkta] ve lezyon veya kabuk bulunabilir; 3 puan: 2,5 cm'den daha fazla kalınlıkta şişkinlik var). Tarsal eklem lezyonları sağım esnasında kolaylıkla puanlanabilir. Puanlamanın ortalama $50 \mathrm{~cm}$ uzaklıktan yapılmasına dikkat edilmelidir (Gibbons ve ark., 2012).

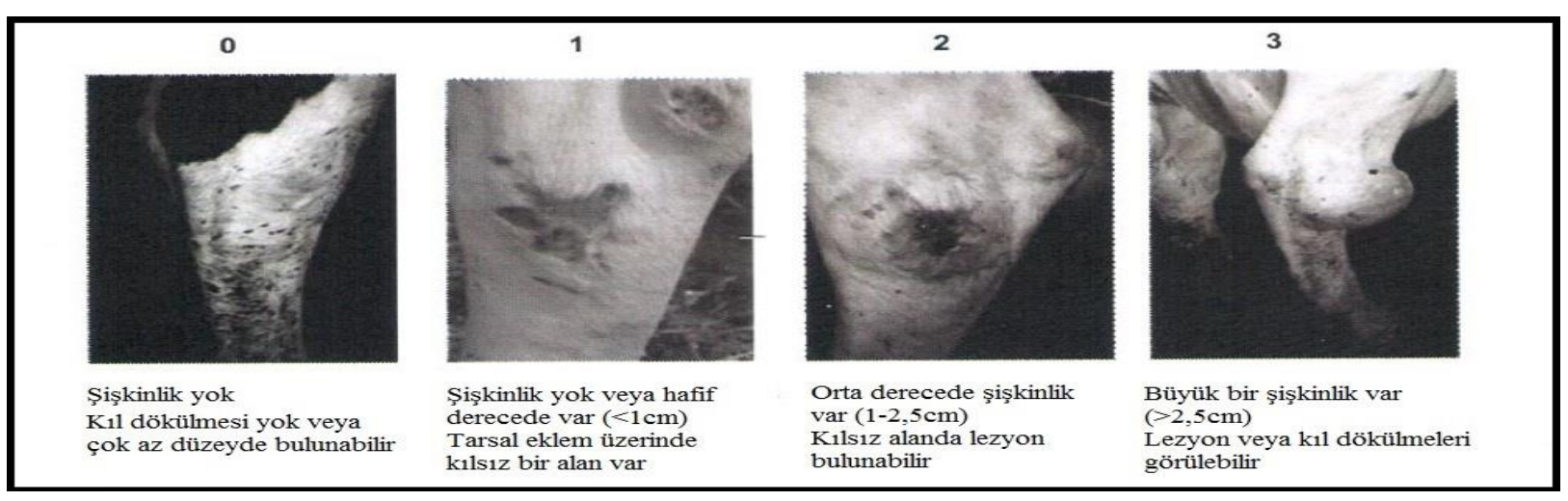

Şekil 5. Tarsal eklemlerin inek konforu açısından değerlendirilmesi (Gibbons ve ark., 2012). 


\section{Karpal Eklem Puanı}

Karpal eklem lezyonları da durak konforunun yetersiz olduğunun göstergesidir ve tarsal eklemler gibi dört derecede puanlanır (Şekil 6). (0 puan, şişkinlik yok, kıl dökülmesi yok veya çok az, 1 puan, şişkinlik yok veya çok az [1 cm'den az kalınlıkta], 2 puan, orta derecede şişkinlik [1-2,5cm ] bulunurken kabuk veya kıl dökülmeleri olabilmekte, 3 puan, , kalınlığ 2,5 cm'den

fazla olan büyük şişkinlik bulunurken, lezyon bulunabilmekte veya bulunmamaktadır). Tarsal ve karpal eklem lezyonlarının beraber değerlendirilmesi daha iyi sonuçlar verir. Çok kirli hayvanların değerlendirilmesi sonuçları yanıltabilmektedir (Gibbons ve ark., 2012).

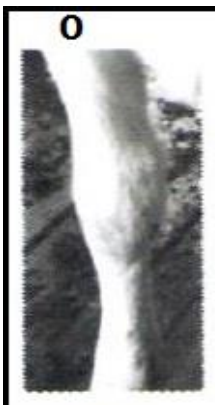

Karpal eklem üzerindeki deride herhangi bir değişiklik yok

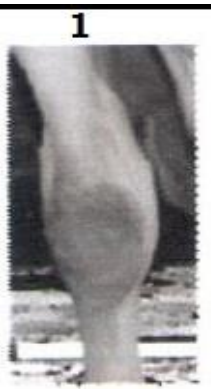

Karpal eklem üzerindeki deride k1ls1z bir alan bulunur

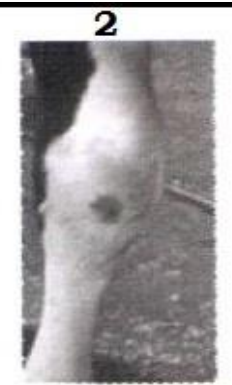

Deride lezyon veya kabuk bulunur ve hafif bir şişkinlik olabilir $(<2,5 \mathrm{~cm})$ K1l dökülmeleri olabilir

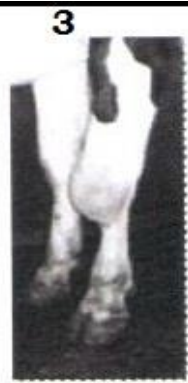

Karpal eklemler üzerinde büyük bir şişkinlik vardır $(>2,5 \mathrm{~cm})$

Deride lezyon veya k1l dökülmeleri bulunabilir

Şekil 6. Karpal eklemlerin inek konforu açısından değerlendirilmesi (Gibbons ve ark., 2012).

\section{Bacak Hijyeni}

Bacakların hijyen durumunun değerlendirilmesi genellikle ineklerin yan bakıdan ve bacakların tarsal eklemler ve aşağısında kalan kısımlarının göz önüne alınarak yapılır (Şekli 7). Bacak hijyen puanının yüksek olması, özellikle serbest duraklı ahırlarda karşılaşılan bir problemdir. Laktasyonun erken dönemlerinde dışkının yumuşak olması, aşırı yoğunluk, dışkının yeterince uzaklaştırılamaması, servis yollarının dar olması ve eğimlerinin yetersiz olması $(<\%$ 1,5) ve ahırda yataklıkların 3 sıralı olması ( 2 sıralıya göre \% 20 az alan kalır) gibi faktörler hijyenin kötü olmasına yol açmaktadır. Bacak hijyen puanlaması dört derecede (1 puan, temiz; 2 puan, hafif kirli; 3 puan, orta derecede kirli; 4 puan, çok kirli) yapılır. Bacak hijyen puanlaması yapılan ineklerin 3 ve 4 puan olanlarının oran $1 \% 25$ 'ten az olmalıdır. Puanlama sonucuna göre 3 ve 4 puanın sürüdeki oranları, uygulanacak ayak banyosunun sıklığını belirlemede de kullanılmaktadır (Cook, 2007).

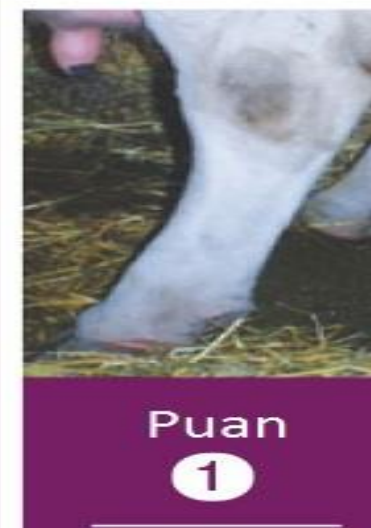

Temiz
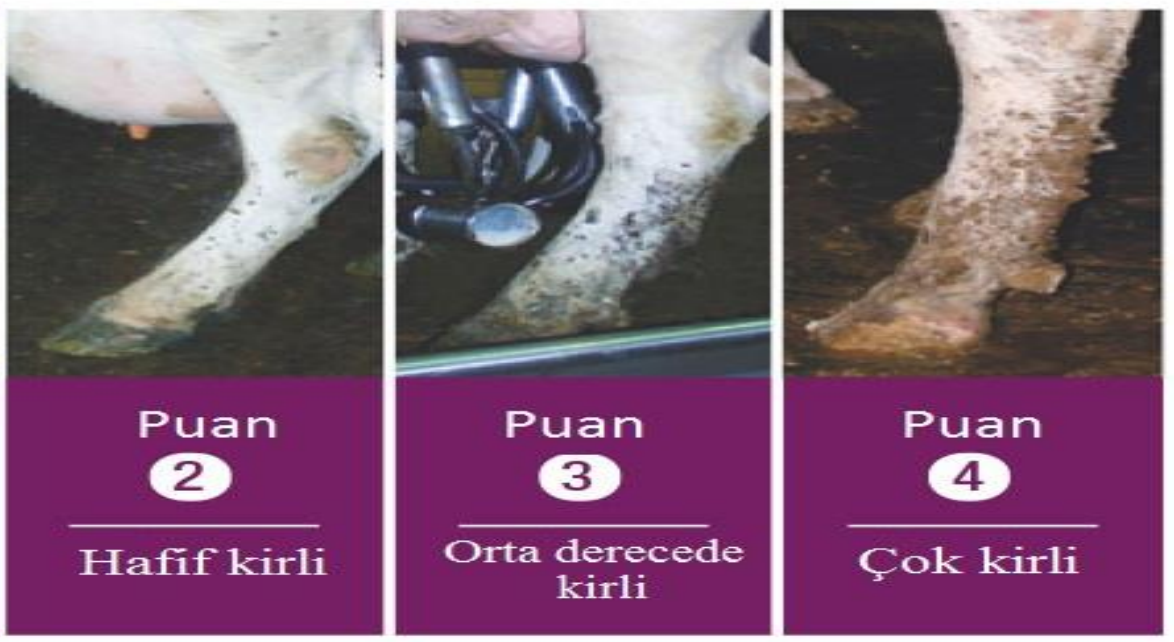

Şekil 7. Bacak hijyeni puanlama kartı (Cook, 2007) 


\section{Sonuç ve Öneriler}

İşletmede hayvan sağlığı ve refahını sürdürebilmek ve verimi arttırmak için ineklerin yatarak dinlenebilecekleri konforlu, temiz ve yeterli alanlar sağlanmalıdır (Bernardi ve ark., 2009; Cook ve Nordlund, 2004a). Hayvanların yatma ihtiyaçlarını karşılayabilmesi için durak ölçülerinin hayvanların büyüklüğüne uygun olarak düzenlenmesi önemli olmakla birlikte; durak konforunun arttırılması çok daha önemlidir. Zeminlerin sertliği ve kayganlığı koryumda travmalara neden olurken, aşındırıcılığı ise tırnağın biçimini etkilemektedir. Zeminlerin olumsuz etkileri, hayvanların ayakta durma sürelerini kısaltan ve yatmalarını teşvik eden yönetimsel uygulamalarla oldukça hafifletilebilir (Bell ve Weary, 2000). Hayvanların yoğun olarak kullandığı yüzeylere kauçuk mat serilmesi zeminlerin olumsuz etkilerini azaltması ve yürüyüş konforunu arttırması bakımından etkili bir yöntem olarak önerilmektedir (Norberg, 2013).

Ayak banyoları enfeksiyöz ayak hastalıklarının kontrolünde çok yaygın bir şekilde kullanılmaktadır ayrıca Thomsen ve ark. (2012) suyla ayakları yıkamanın digital dermatitisi \% 30, sabunlu suyla yıkamanın ise \% 50 oranında azalttığını belirtmektedir. Otomatik ayak yıkama uygulamalarının gelecekte topallıkların kontrolünde yaygın olarak kullanılacağı öngörülmektedir (Bergsten, 2013).

Geçiş dönemi, topallık kontrolünde kilit noktalardan biri olmalıdır (Blowey, 2005). Doğum sürecinin tırnak sağlığına olan olumsuz etkilerini önlemek için bu dönemde ineklerin konforu mümkün olduğunca arttırılmalı (Huzzey ve ark., 2005) ve kuru dönem başlangıcında fonksiyonel tırnak kesimi yaparak doğum sürecinde tırnağın en uygun biçimde olması sağlanmalıdır (Blowey, 2005). Geçiş dönemi ahırlarının, ineklerin davranışları ve bu dönemdeki özel ihtiyaçları göz önüne alınarak tasarlanması oldukça önemlidir (Cook ve Nordlund, 2004b). Doğum sürecinde tırnaklarda şekillenen değişiklikler göz önüne alındığında, geçiş dönemindeki ineklerin tırnaklarının, laktasyonun diğer dönemindeki ineklere göre travmalara karşı daha duyarlı olduğu söylenebilir.

Hayvanlara yeterince egzersiz yaptırılmaması ve uzun süre ayakta bekletilmesi tırnaklardaki kan dolaşımını bozarak, koryumda iskemi ve hipoksiye neden olmaktadır. Tırnaklarda düzenli kan dolaşımının sağlanabilmesi için hayvanın yeterince yürümesinin ve yatma ihtiyacının karşılaması gerekmektedir (Greenough, 2007). İşletme yöneticisi ve hayvan bakıcılarının hayvan konforu ve konforun iyileştirilmesi konusunda bilgilendirilmesi işletme ve hayvan açsından önemli yararlar sağlayacaktır. Konforun iyileştirilmesi ile hayvan refahı artırılacak, hastalıklar ve hastalıklara bağlı bağlı verim düşüşü, tedavi giderleri ve ayıklamalar azalacaktır.

\section{Kaynaklar}

Akköse, M., İzci, C. 2017. Süt ineklerinde yatma süresinin topallıklara etkisi ve yatma süresini etkileyen faktörler. Lalahan Hay. Araşt. Enst. Derg. 57(1), 44-51.

Ayyılmaz, T., Uzmay, C., Kaya, İ. 2011a. Süt sığırlarında inek konforu esaslı durak konforu tasarımı. Hayvansal Üretim, 52(2): 46-57.

Ayyılmaz, T., Uzmay, C., Kaya, İ. 2011b. İneklerde konforun artırılması açısından serbest durak tasarımı. 7. Ulusal Zootekni Bilim Kongresi, 14-16 Eylül, Adana.

Bell, E., Weary, DM. 2000. The effects of farm environment and management on laminitis. 35th Annual Pacific Northwest Animal Nutrition Conference, 3-5 October, Spokane, Washington.

Bergsten, C. 2010. Impact of flooring on claw health and lameness. Adv. Dairy Tech. 22: 241-251.

Bergsten, C. 2013. Walking and standing surfaces for longevity. These floors are made for walking. Cow Longevity Conference, 28-29 August, Tumba, Sweden.

Bernardi, F., Fregonesi, J., Winckler, C., Veira, D.M., Keyserlink, M.A.G., Weary, D.M. 2009. The stall design paradox: neck reil increase lameness but improve udder and stall hygiene. J. Dairy Sci. 92: 3074-3080. DOI: http://dx.doi.org/10.3168/jds.2008$\underline{1166}$

Bicalho, R.C. 2011. Lameness in dairy cattle: a dabilitating disease or a disease of dabilitated cattle? Western Dairy Management Conference, 9-11 March, Reno, NV.

Bicalho, R.C., Mashado, V.S., Caixeta, L.S. 2009. Lameness in dairy cattle: a dabilitating disease or a disease of dabilitated cattle? A cross sectional study of lameness prevalence and thickness of the digital cushion. J. Dairy Sci. 92: 3175-3184. DOI: http://dx.doi.org/10.3168/jds.2008-1827

Blowey, R. 2015. Cattle Lameness and Hoofcare. 3rd edition, 5m Publishing, QN.

Blowey, R. 2005. Factors associated with lameness in dairy cattle. In Practice, 27: 154-162. DOI:10.1136/inpract.27.3.154

Booth, C.J., Warnick, L.D., Gröhn, Y.T., Maizon, D.O., Guard, C.L., Janssen, D. 2004. Effect of lameness on culling in dairy cows. J. Dairy Sci. 87: 4115-4122. DOI: http://dx.doi.org/10.3168/jds.S0022- 
$\underline{0302(04) 73554-7}$

Chapinal, N., von Keyserlingk, M.A.G., Cerri, R.L.A., Ito, K., LeBlanc, S.J., Weary, D.M. 2013. Short communication: Herd-level reproductive performance and its relationship with lameness and leg injuries in freestall dairy herds in the northeastern United States. J. Dairy Sci. 96: 7066-7072. DOI: http://dx.doi.org/10.3168/jds.2013-6967

Cook, N.B. 2003. Prevalence of lameness among dairy cattle in Wisconsin as a function of hausing type and stall surface. J. Am. Vet. Med. Assoc. 223:1324-1328. DOI: $10.2460 /$ javma.2003.223.1324

Cook, N.B. 2007. A guide to investigating herd lameness problem.

http://www.milkproduction.com/Library/Scientificarticles/Animal-health/A-guide-to-investigating-aherd-lameness-problem/ (Erişim: 15 Ocak 2016)

Cook, N.B. 2008. The influences of cow comfort on herd lameness dynamics. The 15th International Symposium \& the 7th Conference on Lameness in Ruminants. 9-13 June, Kuopio, Finland.

Cook, N.B., Bennett, T.B., Nordlund, K.V. 2005. Monitoring indices of cow comfort in free-stall-housed dairy herds. J. Dairy Sci. 88: 3876-3885. DOI: http://dx.doi.org/10.3168/jds.S00220302(05)73073-3

Cook, N.B., Bennett, T.B., Nordlund, K.V. 2004. Effect of free stall surface on daily activity patterns in dairy cows with relevance to lameness prevalence. J. Dairy Sci.

87:

2912-2922.

DOI: http://dx.doi.org/10.3168/jds.S00220302(04)73422-0

Cook, N.B., Nordlund, K.V. 2004a. An update on dairy cow freestall design. Bovine Practitioner, 39: 29-36.

Cook, N.B., Nordlund, K.V. 2004b. Behavioral needs of the transition cow and considerations for special needs facility design. Vet. Clin. North Am. Food Anim. Pract. 20: 495-520. DOI: http://dx.doi.org/10.1016/j.cvfa.2004.06.011

Cook, N.B., Mentink, R.L., Bennett, T.B., Burgi, K. 2007. The effect of heat stress and lameness on time budgets of lactating dairy cows. J. Dairy Sci. 90: 1674-1682. DOI: http://dx.doi.org/10.3168/jds.2006-634

Dippel, S., Dolezal, M., Brenninkmeyer, C., Brinkman, J., March, S., Knierim, U., Winckler, C. 2009. Risk factor lameness in freestall-housed dairy cows across two breeds, farming system and countries. J. Dairy Sci. 92: 5476-5486. DOI: http://dx.doi.org/10.3168/jds.2009-

\section{$\underline{2288}$}

Drissler, M., Gaworski, M., Tucker, C.B., Weary, D.M. 2005. Freestall maintenance: effects on lying behavior of dairy cattle. J. Dairy Sci. 88: 2381-2387. DOI: http://dx.doi.org/10.3168/jds.S0022$\underline{0302(05) 72916-7}$

Endres, M.I. 2012. Bedding options for dairy cows. Adv. Dairy Tech. 24: 361-369.

Endres M.I. 2017. The relationship of cow comfort and flooring to lameness disorders in dairy cattle. Vet. Clin. North Am. Food Anim. Pract. 33(2): 227-233. DOI: 10.1016/j.cvfa.2017.02.007

Espejo, L.A., Endres, M.I., Salfer, J.A. 2006. Prevalence of lameness in high producing holstein cows housed in freestall barns in Minnesota. J. Dairy Sci. 89: 30523085. DOI: $10.3168 /$ jds.S0022-0302(06)72579-6

Fjeldaas, T., Sogstad, A.M., Østerås, O. 2011. Locomotion and claw disorders in Norwegian dairy cows housed in freestalls with slatted concrete, solid concrete, or solid rubber flooring in the alleys. J. Dairy Sci. 94: 1243 1255. DOI: http://dx.doi.org/10.3168/jds.2010-3173

Fregonesi, J.A., von Keyserlink, M.A.G., Tucker, C.B., Veira, D.B., Weary, D.M. 2009. Neck-rail position in the freestall affects standing behavior and udder and stall cleanliness. J. Dairy Sci. 92: 1979-1985 DOI: http://dx.doi.org/10.3168/jds.S0022$\underline{0302(04) 73271-3}$

Gantner, V., Mijić, P., Kuterovac, K., Solić, D., Gantner, R. 2011. Temperature-humidity index values and their significance on the daily production of dairy cattle. Mljekarstvo. 61(1); 56-63. UDK: 637.112

Garbarino, E.J., Hernandez, J.A., Shearer, J.K., Risco, C.A., Tatcher, W.W. 2004. Effect of lameness on ovarian activity in postpartum holstein cows. J. Dairy Sci. 87 4123-4131.

DOI: http://dx.doi.org/10.3168/jds.S00220302(04)73555-9

Gibbons, J., Vasseur, E., Rushen, J., de Passillé, A.M. 2012. A training programme to ensure high repeatability of injury scoring of dairy cows. Animal Welfare, 21: 379-388. DOI: $\underline{10.7120 / 09627286.21 .3 .379}$

Gomez, A., Cook, N.B. 2010. Time budgets of lactating dairy cattle in commercial freestall herds. J. Dairy Sci. 93: 5572-5781.

DOI: http://dx.doi.org/10.3168/jds.2010-3436

Gooch, C.A. 2012. Flooring considerations for dairy cattle. 
http://articles.extension.org/pages/65155/flooringconsiderations-for-dairy-cows (Erişim: 20 Temuz 2016)

Graves, R. E., McFarland, D. F., Tyson, J. T. 2009. Designing and building dairy cattle freestalls. http://extension.psu.edu/animals/dairy/health/facilities /designing-building-dairy-cattle-

freestalls/extension_publication_file (Erişim: 10 Mart 2016)

Greenough, P.R. 2007. Bovine Laminitis and Lameness A Hands of Approach. 1th ed. Saunders, Toronto.

Haskell, M.J., Rennie, L.J., Bowell, V.A., Bell, M.J., Lawrence, A.B. 2006. Housing system, milk production, and zero-grazing effects on lameness and leg injury in dairy cows. J. Dairy Sci. 89: 4259-4266. DOI: http://dx.doi.org/10.3168/jds.S0022$\underline{0302(06) 72472-9}$

Herlin, A.H. 1997. Comparison of lying area surfaces for dairy cows by preference, hygiene, and lying down behaviour. Swed. J. Agri. Res., 27: 189-196.

Hernandez, J.A., Garbarino, E.J., Shearer, J.K., Risco, C.A., Thatcher, W.W. 2005a. Comparison of the calving-to-conception interval in dairy cows with different degrees of lameness during the prebreeding postpartum period. J. Am. Vet. Med. Assoc. 227: 1284-1291. DOI: $10.2460 /$ javma.2005.227.1284

Hernandez, J.A., Garbarino, E.J., Shearer, J.K., Risco, C.A., Thatcher, W.W. 2005b. Comparison of milk yield in dairy cows with different degrees of lameness. J. Am. Vet. Med. Assoc. 227: 1292-1296. DOI: 10.2460/javma.2005.227.1292

Hulsen, J. 2010. Cow signals. A practical guide for dairy farm manegement. Rood Bond Publishers, Zutphen, Netherlands.

Huzzey, J.M., von Keyserlingk, M.A.G., Weary, D.M. 2005. Changes in feding, drinking, and standing behavior of dairy cows during the transition period. J. Dairy Sci. 2454-2461. DOI: http://dx.doi.org/10.3168/jds.S00220302(05)72923-4

İzci, C., Erol, M., Gökşahin, E. 2011. A study about determining the changes in the structural characteristics of the digital cushion in heifer and multipar dairy cows: A preliminary report. Kafkas Univ. Vet. Fak. Derg. 17(1): 159-162. DOI: $10.9775 / \mathrm{kvfd} .2010 .3083$

İzci, C., Akköse, M., Gerçekcioğlu, M., 2016. Süt sığırcılığı işletmelerinde yapılan topallık skorlaması sonuçlarının değerlendirilmesi. 15'inci Ulusal
Veteriner Cerrahi Kongresi ve 1'th International Turkey Veterinary Surgery Congress,11-14 May1s, Erzurum.

Jungbluth, T., Benz, B., Wandel, H., 2003. Soft walking areas in loose housing systems for dairy cows. American Society of Agricultural and Biological Engineers. In Fifth International Dairy Housing Proceedings of the 29-31 January 2003 Conference, (Fort Worth, Texas, USA), 171-177. DOI: $\underline{10.13031 / 2013.11618}$

Lischer, C.J., Ossent, P. 2002. Pathogenesis of sole lesions attributed to laminitis in cattle. 12th International Symposium on Lameness in Ruminants, Orlando, Florida, USA.

Manske, T., Hultgren, J., Bergsten, C. 2002. The effect of claw trimming on the hoof health of Swedish dairy cattle. Prev. Vet. Med. 54, 113-129.

Margerison, J.K., Lau, J., Hedley, M.J., Horne, D.J., Hanly, J.A., Powell, N., Shilton, A. 2014. Lying and feeding behaviour of dairy cows at pasture and housed in freestalls fitted with sand and water filled matts. 27th Annual FLRC Workshop, February, New Zelland.

Munksgaard, L., Jensen, M.B., Pedersen, L.J., Hansen, S.W., Matthews, L. 2005. Quantifying behavioural priorities-effect of time constraints on behaviour of dairy cows. Appl. Anim. Behav. Sci. 92: 3-14. DOI: http://dx.doi.org/10.1016/j.applanim.2004.11.00 $\underline{5}$

Mülling, C.K.W., Green, L., Barker, Z., Scaife, J., Amory, J., Speijer, M. 2006. Risk factors associated with foot lameness in dairy cattle and a suggested approach for lameness reduction. World Buiatrich Congress, Nice, France.

Mülling, C.K.W. 2009. Environmental influences on claw function and integrity. CanWest Veterinary Conference, Banff, Alberta.

Newsome, R.F., Green, M.J., Bell, N.J., Bollard, N.J., Mason, C.S., Whay, H.R., Huxley, J.N. 2017a. A prospective cohort study of digital cushion and corium thickness. Part 1: Associations with body condition, lesion incidence, and proximity to calving. J Dairy Sci. 100(6):4745-4758. DOI: 10.3168/jds.2016-12012

Newsome, R.F., Green, M.J., Bell, N.J., Bollard, N.J., Mason, C.S., Whay, H.R., Huxley, J.N. 2017b. A prospective cohort study of digital cushion and corium thickness. Part 2: Does thinning of the digital cushion and corium lead to lameness and claw horn disruption lesions? J Dairy Sci. 100(6): 4759-4771. DOI: $\underline{10.3168 / \mathrm{jds} .2016-12013}$ 
Nocek, J.E. 1997. Bovine acidosis: implications on laminitis. J. Dairy Sci. 80: 1005-1028. DOI: 10.3168/jds.S0022-0302(97)76026-0

Norberg, P. 2013. Effects of rubber alley flooring on cow locomotion and welfare. http://www.milkproduction.com/Library/Scientificarticles/Animal-health/Effects-of-rubber-alleyflooring-on-cow-locomotion-and-welfare/ (Erişim: 10 Şubat 2016)

O’Callaghan, K.A., Cripps, P.J., Downham, D.Y., Murray, R.D. 2003. Subjective and objective assessment of pain and discomfort due to lameness in dairy cattle. Animal Welfare, 12: 605-610.

Ouweltjes, W., van der Werf, J.T.N., Frankena, K., van Leeuven, J.L. 2011. Effect of flooring and restricted freestall, access on behavior and claw health of dairy heifers. J. Dairy Sci. 94: 705-715. DOI: http://dx.doi.org/10.3168/jds.2010-3208

Phillips, C.J.C., Morris, I.D., 2001. The locomotion of dairy cows on floor surfaces with different frictional properties. J. Dairy Sci. 84: 623-628. DOI: http://dx.doi.org/10.3168/jds.S0022$\underline{0302(01) 74517-1}$

Platz, S., Ahrens, F., Bendel, J., Meyer, H. H. D., Erhard, M. H., 2008. What happens with cow behavior when replacing concrete slatted floor by rubber coating: A case study. J. Dairy Sci. 91: 999-1004. DOI: http://dx.doi.org/10.3168/jds.2007-0584

Proudfoot, K.L., Weary, D.M., von Keyserlingk, M.A.G. 2010. Behavior during transition differs for cows diagnosed with claw horn lesions in mid lactation. J. Dairy Sci. 93: 3970-3978. DOI: http://dx.doi.org/10.3168/jds.2009-2767

Rushen, J., de Passillé, A.M., 2009. Flooring options to minimize lameness and optimize welfare. Adv. Dairy Tech. 21: 293-301.

Sepulveda-Varas, P., Weary, D.M., von Keyserlingk, M.A.G. 2014. Lying behavior and postpartum health status in grazing dairy cows. J. Dairy Sci. 97: 63346344. DOI: http://dx.doi.org/10.3168/jds.2014-8357

Shearer, J.K., van Amstel, S.R., 2007. Effect of flooring and/or flooring surfaces on lameness disorders in dairy cattle. Western Dairy Management Conference, March 7-9 Reno, NV.

Shearer, J.K. 2010. Nutritional and animal welfare implications to lameness. Tri-State Dairy Nutrition Conference, Fort Wayne, Indiana.

Sogstad, A.M., Fjeldaas, T., Qsteras, O., Plym-Forshell, K.
2005. Prevalence of claw lesions in Norwegian dairy cattle housed in tie stalls and free stalls. Prev. Vet. Med., 70(3-4):191-209.

DOI:

10.1016/j.prevetmed.2005.03.005

Solano, L. 2013. Decreasing lameness and increasing cow comfort on Alberta dairy farms. Adv. Dairy Tech. 25: 297-306.

Solano, L., Barkema, H.W., Pajor, E.A., Mason, S., LeBlanc, S.J., Nash, C.G.R., Haley, D.B., Pellerin, D., Rushen, J., de Passillé, A.M., Vasseur, E., Orsel, K. 2016. Associations between lying behavior and lameness in Canadian Holstein-Friesian cows housed in freestall barns. J. Dairy Sci. 99: 2086-2101. DOI: http://dx.doi.org/10.3168/jds.2015-10336

Somers, J.G., Frankena, K., Noordhuizen-Stassen, E.N., Metz, J.H., 2005. Risk factors for digital dermatitis in dairy cows kept in cubicle houses in The Netherlands. Prev. Vet. Med., 71(1-2): 11-21. DOI: 10.1016/j.prevetmed.2005.05.002

Sprecher, D.J., Hostetler, D.E., Kaneene, J.B. 1997. A lameness scoring system that uses posture and gait to predict dairy cattle reproductive performance. Theriogenology, 47: 1179-1187. DOI: http://dx.doi.org/10.1016/S0093691X(97)00098-8

Tarlton, J.F., Holah, D.E., Evans, K.M. 2002. Biomechanical and histopathological changes in the support structures of bovine hooves around the time of first calving. Veterinary Journal 163: 196-204. DOI: $10.1053 /$ tvj1.2001.0651

Tarlton, J.F., Webster, A.J.F. 2002. A biochemical and biomechanical basis for the pathogenesis of claw horn lesions. Proceedings of the 12'th International Symposium on Lameness in Ruminants, 9-13 January, Orlando, USA.

Telezhenko, E., Bergsten, C. 2005. Influence of floor type on the locomotion of dairy cows. Appl. Anim. Behav. Sci. 93(3-4):183-197. DOI: http://dx.doi.org/10.1016/j.applanim.2004.11.021

Telezhenko, E., Lidfors, L., Bergsten, C. 2007. Dairy cow preferences for soft or hard flooring when standing or walking. J. Dairy Sci. 90: 3716-3724. DOI: http://dx.doi.org/10.3168/jds.2006-876

Telezhenko, E., Bergsten, C., Magnusson, M., Nilsson, C. 2009. Effect of different flooring systems on claw conformation of dairy cows. J. Dairy Sci. 92: 26252633. DOI: http://dx.doi.org/10.3168/jds.2008-1798

Thomsen, P.T., Ersboll, A.K., Sorensen, J.T. 2012. Short communication: Automatic washing of hooves can help control digital dermatitis in dairy cows. J. Dairy 
Sci.

95;

7195-7199.

DOI: http://dx.doi.org/10.3168/jds.2011-5171

Toussaint-Raven, E. 2003. Cattle Footcare and Claw Trimming. 3th ed. Crowood Press, Ipswich, p. 59.

Tucker, C.B., Weary, D.M. 2004. Bedding on geotextile mattresses: how much is needed to improve cow comfort? J. Dairy Sci. 87: 2889-2895. DOI: http://dx.doi.org/10.3168/jds.S00220302(04)73419-0

Tucker, C.B., Weary, D.M., Fraser, D. 2004. Free-stall dimention: effects on preference and stall usage. J. Dairy Sci. $\quad$ 87: 1208-1216. DOI: http://dx.doi.org/10.3168/jds.S00220302(04)73271-3

Tucker, C.B., Weary, D.M., Fraser, D. 2005. Influence of neck-rail placement on freestall preference, use, and cleanliness. J. Dairy Sci. 88: 2730-2737. DOI: http://dx.doi.org/10.3168/jds.S00220302(05)72952-0

Tucker, C.B., Zdanowicz, G., Weary, D.M. 2006. Brisket boards reduce freestall use. J. Dairy Sci. 89: 26032607. DOI: http://dx.doi.org/10.3168/jds.S00220302(06)72337-2

Uslucan, B., Özkütük, K. 2007. Entansif süt sı̆̆ırı yetiştiriciliğinde altlık materyallerin kullanımı, önemi ve çeşitleri. 3. Ulusal Zootekni Öğrenci Kongresi, $17-$ 18 Mayıs, Kahramanmaraş.

van der Tol, P.P.J., Metz, J.H.M., Noordhuizen-Stassen, E.N., Back, W., Braam, C.R., Weijs, W.A. 2005. Frictional forces required for unrestrained locomotion in dairy cattle. J. Dairy Sci. 88: 615-624. DOI: http://dx.doi.org/10.3168/jds.S00220302(05)72725-9

van Eerdenburg, F.J.C.M. 2013. Lying area design and barn climate getting it right. Cow Longevity Conference, 28-29 August, Tumba, Sweden.

Vanegas, J., Overton, M., Berry, S.L., Sischo, W.M. 2006. Effect of ruber floring on claw health in lactating dairy cows housed in free-stall barns. J. Dairy Sci. 89: 42514258. DOI: http://dx.doi.org/10.3168/jds.S00220302(06)72471-7

von Keyserlingk, M.A.G., Cunha, G.E., Fregonesi, J.A., Weary, D.M. 2011. Introducing heifers to freestall housing. J. Dairy Sci. 94: 1900-1907. DOI: http://dx.doi.org/10.3168/jds.2010-3994

Wagner-Storch, A.M., Palmer, R.W., Kammel, D.W. 2003. Factors affecting stall use for different freestall bases. J. Dairy Sci. 86: 2253-2266. DOI: http://dx.doi.org/10.3168/jds.S0022$\underline{0302(03) 73816-8}$

Walker, S.L., Smith, R.F., Routly, J.E., Jones, D.N., Morris, M.J., Dobson, H. 2008. Lameness, activity time-budget, and estrus expression in dairy cattle. J. Dairy Sci. 91: 4552-4559. DOI: http://dx.doi.org/10.3168/jds.2008-1048

Warnick, L.D., Janssen, D., Guard, C.L., Gröhn, Y.T. 2001. The effect of lameness on milk production in dairy cows. J. Dairy Sci. 84: 1988-1997. DOI: http://dx.doi.org/10.3168/jds.S0022$\underline{0302(01) 74642-5}$

Yaylak, E. 2008. Süt sığırlarında topallık ve topallığın bazı özelliklere etkisi. Hayvansal Üretim 49(1): 47-56.

Yaylak, E., Akbaş, Y., Kaya, İ., Uzmay C. 2010. The effects of several cow and herd level factors on lameness in Holstein Cows reared in İzmir province of Turkey. Journal of Animal and Veterinary Advances, 9(21): 2714-2722. DOI: $10.3923 /$ javaa.2010.2714.2722 